\title{
Regulation of Glucose Utilization in Adipose Cells and Muscle After Long-term Experimental Hyperinsulinemia in Rats
}

Lawrence J. Wardzala, Michael Hirshman, Eric Pofcher, Elizabeth D. Horton, Patricia M. Mead, Samuel W. Cushman, and Edward S. Horton

Metabolic Unit, Department of Medicine, University of Vermont College of Medicine, Burlington, Vermont 05405; and Cellular Metabolism and Obesity Section, NIADDK-NIH, Bethesda, Maryland 20205

\begin{abstract}
The effects of chronic insulin administration on the metabolism of isolated adipose cells and muscle were studied. Adipose cells from 2 and 6 wh insulin-treated and control rats, fed either chow or chow plus sucrose, were prepared, and insulin binding, 3-O-methylglucose transport, glucose metabolism, and lipolysis were measured at various insulin concentrations. After 2 wk of treatment, adipose cell size and basal glucose transport and metabolism were unaltered, but insulin-stimulated transport and glucose metabolism were increased two- to threefold when cells were incubated in either $0.1 \mathrm{mM}$ glucose (transport rate limiting) or $10 \mathrm{mM}$ glucose (maximum glucose metabolism). Insulin binding was increased by $30 \%$, but no shift in the insulin dose-response curve for transport or metabolism occurred. After 6 wk of treatment, the effects of hyperinsulinemia on insulin binding and glucose metabolism persisted and were superimposed on the changes in cell function that occurred with increasing cell size in aging rats. Hyperinsulinemia for 2 or 6 wk did not alter basal or epinephrine-stimulated lipolysis in adipose cells or the antilipolytic effect of insulin. In incubated soleus muscle strips, insulin-stimulated glucose metabolism was significantly increased after 2 wk of hyperinsulinemia, but these increases were not observed after 6 wk of treatment. We conclude that 2 wk of continuous hyperinsulinemia results in increased insulin-stimulated glucose metabolism in both adipose cells and soleus muscle. Despite increased insulin binding to adipose cells, no changes in insulin sensitivity were observed in adipose cells or muscle. In adipose cells, the increased glucose utilization resulted from both increased transport (2 wk only) and intracellular glucose metabolism (2 and 6 wk). In muscle, after 2 wk of treatment, both glycogen synthesis and total glucose metabolism were increased. These effects of hyperinsulinemia were lost in muscle after 6 wk of treatment, when compared with sucrose-supplemented controls.
\end{abstract}

\section{Introduction}

Hyperinsulinemia and insulin resistance of adipose and muscle tissue have been observed in several animal models (1-11) of

This work was presented in part at the Annual Meeting of the American Diabetes Association, San Antonio, TX, 1983, and was reported in abstract form in Diabetes. 1983. 32(Suppl.)1:98.

Address correspondence to Dr. Horton, University of Vermont College of Medicine.

Received for publication 25 October 1983 and in revised form 17 April 1985.

J. Clin. Invest.

(c) The American Society for Clinical Investigation, Inc.

0021-9738/85/08/0460/10 \$1.00

Volume 76, August 1985, 460-469 obesity. Although the cause of the insulin resistance in these models is not completely understood, it has been proposed that it is secondary to increased plasma insulin concentrations (8-12). It has been shown by several investigators that chronic hyperinsulinemia is associated with decreased tissue responsiveness $(7,8,12)$. Gavin et al. (13) have proposed that this may be secondary to a loss of cellular insulin receptors.

Recently, Kobayashi and Olefsky (14) and Whittaker et al. (15) have demonstrated that chronic hyperinsulinemia, induced by daily injections of insulin, is associated with a reduced concentration of insulin receptors in adipose cells and a decrease in cellular insulin sensitivity consistent with the concept of down-regulation of the insulin receptor. However, Kobayashi and Olefsky $(14,16)$ have also reported that chronic hyperinsulinemia has significant postreceptor effects on glucose transport and metabolism. Both basal and insulin-stimulated glucose transport were found to be increased and insulin sensitivity decreased after 2 wk of insulin administration. In addition, the capacity for intracellular glucose metabolism was increased (17). In contrast, Whittaker et al. (15) found no change in maximal insulin-stimulated glucose transport, although they did confirm a rightward shift in the insulin doseresponse curve and an increase in insulin-stimulated glucose metabolism. These results suggest that chronic hyperinsulinemia has different long-term effects on the down-regulation of the insulin receptor and on glucose transport and metabolism.

The present study was designed to clarify the effects of long-term hyperinsulinemia on insulin binding, glucose transport, and metabolism in adipose cells and to determine if hyperinsulinemia has similar effects on muscle. To determine the relative importance of these parameters of insulin action in the development of insulin resistance, continuous hyperinsulinemia was produced in rats for 2 and 6 wk using subcutaneously implanted osmotic minipumps.

\section{Methods}

Insulin administration. Male CD-strain rats weighing $125 \mathrm{~g}$ were obtained from the Charles River Breeding Laboratories, Boston, MA. Animals were housed three per cage in a room with a 12-h light/dark cycle. The animals were divided into three experimental groups: chowfed controls, sucrose supplemented chow-fed controls, and insulintreated animals with sucrose also supplemented to their chow. The insulin-treated rats received a continuous infusion of regular purified pork insulin (Iletin II, Eli Lilly \& Co., Indianapolis, IN) for either 2 or 6 wk from osmotic minipumps (Alzet No. 2002, Alza Corp., Palo Alto, CA) implanted subcutaneously on their backs. The insulin dose was increased gradually over the treatment period with the following schedule: $2 \mathrm{U} / \mathrm{d}$ for $4 \mathrm{~d}, 4 \mathrm{U} / \mathrm{d}$ for $4 \mathrm{~d}, 6 \mathrm{U} / \mathrm{d}$ for either $6 \mathrm{~d}$ or $5 \mathrm{wk}$, depending upon the length of the study. The insulin was prepared as described by Bringer et al. (18) to prevent aggregation of a concentrated insulin solution.

Body weight and food consumption were measured throughout the treatment period in some experiments. After the treatment period, 
groups of control and insulin-treated animals were killed by a blow to the head and decapitation. Blood was collected for measurements of plasma glucose, insulin, triglyceride, and free fatty acid concentrations. The soleus muscle was rapidly removed for studies of muscle metabolism and for glycogen (19) and triglyceride (20) content. Epididymal adipose tissue was removed for preparation of isolated adipose cells for studies of glucose metabolism, glucose transport, lipolysis, and insulin binding. Samples of liver and gastrocnemius muscle were also obtained for measurement of glycogen and triglyceride content. The carcasses of six insulin treated and six sugar-supplemented control animals treated for $6 \mathrm{wk}$ were prepared for body composition analysis. The gastrointestinal tract was washed clean and the carcasses frozen until analyzed. Before analysis, carcasses were homogenized in a Waring blender and weighed aliquots of the homogenate were freeze dried and ground in a Wiley mill. Nitrogen, fat, and residual ash content were then measured by standard procedures (21).

Preparation of isolated adipose cells. For each experiment, two groups of either chow-fed controls, sugar-supplemented controls, or insulin-treated rats were used (3-4 animals/group). Both epididymal fat pads were removed from each animal, weighed, and placed in Krebs-bicarbonate-Hepes buffer (standard Krebs-Ringer-bicarbonate buffer $(\mathrm{KRB})^{1}$ reduced to $10 \mathrm{mM} \mathrm{HCO}_{3}$ supplemented with $30 \mathrm{mM}$ Hepes, Sigma Chemical Co., St. Louis, MO). Adipose cells were isolated by the method described by Rodbell (22) as modified by Cushman (23). Adipose cell size was measured using the osmic acid fixation-Coulter electronic counter method described by Hirsch and Gallian (24) for intact tissue fragments and modified for isolated cell suspensions by Cushman and Salans (25).

Glucose metabolism. Adipose cells were distributed in 20-ml plastic vials. Final incubation volume was $1.5 \mathrm{ml}$ of KRB-Hepes buffer ( $\mathrm{pH}$ 7.4), containing isolated cells, $30 \mathrm{mg}$ bovine serum albumin $/ \mathrm{ml}$, varying concentrations of insulin (Eli Lilly \& Co.), and $0.1 \mathrm{mM}$ glucose at a specific activity of $\sim 300 \mu \mathrm{Ci}\left[1-{ }^{14} \mathrm{C}\right]$ glucose/mmol (New England Nuclear, Boston, MA). In a separate series of experiments, cells were incubated in the presence of $10 \mathrm{mM}$ glucose with insulin $(1,000 \mu \mathrm{U} /$ $\mathrm{ml})$. The final cell concentration was $\sim 100 \times 10^{3}$ cells $/ \mathrm{ml}$. After 60 min of incubation at $37^{\circ} \mathrm{C},{ }^{14} \mathrm{CO}_{2}$ was collected and $\left[{ }^{14} \mathrm{C}\right]$ triglyceride glycerol and fatty acids were measured. All incubations were carried out in triplicate and all analyses corrected for appropriate blank values obtained from samples incubated in the absence of cells.

Glucose transport. Glucose transport was assessed by the L$\left[{ }^{14} \mathrm{C}\right]$ arabinose uptake method of Foley et al. (26), except that 3-O$\left[{ }^{14} \mathrm{C}\right]$ methylglucose was used as the substrate. The uptake of 3-Omethylglucose was measured at $37^{\circ} \mathrm{C}$ before and at equilibrium. The initial uptake velocity or rate of transport was then calculated from these values after correction for nonspecific 3-O-methylglucose binding, diffusion, and extracellular space. This technique has been validated as a measure of glucose transport activity in cells of widely different sizes, both in the absence and presence of insulin.

After isolation, adipose cells were equally distributed for preincubation at $37^{\circ} \mathrm{C}$ into a series of 5 -ml plastic vials so that the final incubation volume was $0.4 \mathrm{ml}$ of KRB-Hepes buffer (pH 7.4) containing isolated cells and $30 \mathrm{mg} / \mathrm{ml}$ bovine serum albumin with or without insulin. The final cell concentration was $\sim 750 \times 10^{3}$ cells $/ \mathrm{ml}$. After $60 \mathrm{~min}$ of preincubation under these conditions, $0.05 \mathrm{ml}$ of KRBHepes buffer containing unlabeled 3-O-methylglucose (Sigma Chemical Co.), 3-O- $\left[{ }^{14} \mathrm{C}\right]$ methylglucose (New England Nuclear), L-glucose (Sigma Chemical Co.), and L-[1- $\left.{ }^{3} \mathrm{H}\right]$ glucose (New England Nuclear) was added so that the final concentrations of 3-O-methylglucose and L-glucose would be $0.1 \mathrm{mM}(5 \mathrm{mCi} / \mathrm{mmol})$ and $0.1 \mathrm{mM}(25 \mathrm{mCi} / \mathrm{mmol})$, respectively. Incubation at $37^{\circ} \mathrm{C}$ was then carried out for additional periods chosen to yield approximately half-maximal uptakes (2-15 s). After the appropriate incubation periods, $20 \mu \mathrm{l}$ of $10 \mathrm{mM}$ cytochalasin B (Aldrich Chemical Co., Milwaukee, WI) in ethanol was added to

1. Abbreviation used in this paper: KRB, Krebs-Ringer-bicarbonate buffer. stop the facilitated uptake of 3-O-methylglucose. The samples were then placed at room temperature for a short period during which no additional diffusion was observed before sampling. A $0.2-\mathrm{ml}$ sample of cells and incubation medium was separated by centrifugation through oil (27), and assayed for $3-O-\left[{ }^{14} \mathrm{C}\right]$ methylglucose and $\mathrm{L}-\left[1-{ }^{3} \mathrm{H}\right]$ glucose uptake. L-glucose uptake was used to correct 3-O-methylglucose uptake for diffusion and extracellular space. The initial velocity of uptake, or rate of 3-O-methylglucose transport, was then calculated from these values and from simultaneous estimates of equilibrium 3-O-methylglucose uptake (measured after a 60 -min incubation at $37^{\circ} \mathrm{C}$ ) and nonspecific 3-O-methylglucose binding (measured in the presence of cytochalasin B). All incubations were done in sextuplicate.

Steady state ${ }^{125}$ I-insulin binding. Adipose cells were distributed among 5-ml plastic incubation vials so that the final incubation volume was $0.5 \mathrm{ml}$ of KRB-Hepes buffer containing isolated cells, $0.25 \mathrm{ng}$ (tracer) ${ }^{125} \mathrm{I}$-insulin $/ \mathrm{ml}$ (porcine, $\sim 100 \mu \mathrm{Ci} / \mu \mathrm{g}$, New England Nuclear), and $0-1 \times 10^{5} \mathrm{ng}$ native insulin $/ \mathrm{ml}$. The final cell concentration was $\sim 850 \times 10^{3}$ cells $/ \mathrm{ml}$. All incubations were done at $24^{\circ} \mathrm{C}$ in triplicate.

After $60 \mathrm{~min}$ of incubation, $0.2-\mathrm{ml}$ samples of cells and incubation medium were removed, cells were separated from medium by centrifugation through oil, and the separated cells were analyzed for ${ }^{125} \mathrm{I}$ radioactivity (Auto-Gamma scintillation spectrometer, Packard Instrument Co., Downers Grove, IL) and corrected for the appropriate blanks. ${ }^{125}$ I-insulin specific activities were determined in samples of the stock solutions of labeled hormone.

Lipolysis measurements. Adipose cells were distributed among 20 $\mathrm{ml}$ plastic incubation vials to provide a final incubation volume of 0.5 $\mathrm{ml}$ of KRB-Hepes buffer containing isolated cells, $1.0 \mathrm{mg}$ glucose $/ \mathrm{ml}$, and 1-10 $\mu \mathrm{g}$ epinephrine/ml (Sigma Chemical Co.), and, in some experiments, varying concentrations of insulin $(0-100 \mu \mathrm{U} / \mathrm{ml})$.

The final cell concentration was $100 \times 10^{3}$ cells $/ \mathrm{ml}$. All incubations were done in triplicate, and all analyses were corrected for the appropriate blank values obtained from samples of cells incubated for $1 \mathrm{~min}$ in an ice bath. At the end of the $30-\mathrm{min}$ incubation, a $0.5-\mathrm{ml}$ sample of cell-free medium was aspirated from each tube and chilled in an ice bath. Glycerol was assayed enzymatically in $0.2 \mathrm{ml}$ of the cell-free medium (28). Fatty acids were extracted from $0.2 \mathrm{ml}$ of the cell-free medium, as described by Dole (29). Free fatty acids were assayed by the radioactive method described by Ho and Meng (30), as modified by Cushman et al. (31).

Incubation of soleus muscles and biochemical measurements. Rats were killed by cervical dislocation. Weight-standardized (25-35 mg wet weight) strips of soleus muscle with their respective tendons were removed, and incubated as previously described (1). Incubations were carried out in a shaking incubator at $37^{\circ} \mathrm{C}$, in $25-\mathrm{ml}$ Erlenmeyer flasks with $4 \mathrm{ml}$ KRB containing $1.5 \%$ defatted bovine serum albumin. Flasks were sealed with rubber stoppers and gassed continuously with $\mathrm{O}_{2} / \mathrm{CO}_{2}$ mixture (19:1). Actual incubations were preceded by 30 -min preincubations with continuous gassing, at the end of which flasks and medium were changed. Basal and insulin-stimulated $(0-1,000 \mu \mathrm{U} / \mathrm{ml})$ glycolysis and de novo glycogen synthesis were measured, respectively, from the rate of incorporation of ${ }^{3} \mathrm{H}$ from $\mathrm{D}-\left[5-{ }^{3} \mathrm{H}\right]$ glucose $(5 \mathrm{mM})$ into the ${ }^{3} \mathrm{H}_{2} \mathrm{O}$ released into incubation medium and of ${ }^{3} \mathrm{H}$ into glycogen (32). Total glucose metabolism was assessed by summing these two parameters.

\section{Results}

Body composition and characteristics of experimental animals. Total body weight, epididymal fat pad weight and adipose cell size, liver weight, triglyceride and glycogen content, muscle triglyceride and glycogen content, and plasma concentrations of glucose, insulin, free fatty acids, and triglycerides for the three experimental groups after 2 wk of treatment are given in Table I. Similar data for the groups treated for 6 wk are shown in Table II. 
Table I. Group Comparisons at End of 2-wk Study

\begin{tabular}{|c|c|c|c|c|}
\hline & $\begin{array}{l}\text { Chow-fed } \\
\text { controls }\end{array}$ & $\begin{array}{l}\text { Sugar-supplemented } \\
\text { controls }\end{array}$ & $\begin{array}{l}\text { Insulin-treated } \\
\text { animals }\end{array}$ & $\begin{array}{l}\text { Group } \\
\text { comparisons }\end{array}$ \\
\hline \multicolumn{5}{|l|}{ Body and organ weights } \\
\hline Body weight $(g)$ & $\begin{array}{r}261 \pm 4 \\
(19)\end{array}$ & $\begin{array}{r}264 \pm 5 \\
(22)\end{array}$ & $\begin{array}{r}257 \pm 5 \\
(23)\end{array}$ & \\
\hline Liver weight $(g)$ & $\begin{array}{c}13.20 \pm 0.72 \\
(8)\end{array}$ & $\begin{array}{c}13.82 \pm 0.92 \\
(8)\end{array}$ & $\begin{array}{c}11.43 \pm 0.57 \\
(12)\end{array}$ & $\mathrm{S} / \mathrm{I} P<0.05$ \\
\hline Epididymal fat pad weight $(g)$ & $\begin{array}{l}1.68 \pm 0.11 \\
(19)\end{array}$ & $\begin{array}{c}1.85 \pm 0.11 \\
(22)\end{array}$ & $\begin{array}{l}2.00 \pm 0.13 \\
(23)\end{array}$ & \\
\hline Adipose cell size ( $\mu$ g lipid/cell) & $\begin{array}{c}0.137 \pm 0.018 \\
(5)\end{array}$ & $\begin{array}{c}0.150 \pm 0.016 \\
(6)\end{array}$ & $\begin{array}{c}0.144 \pm 0.009 \\
(6)\end{array}$ & \\
\hline \multicolumn{5}{|l|}{ Plasma concentrations } \\
\hline Glucose $(m g / d l)$ & $\begin{array}{r}148 \pm 3 \\
(19)\end{array}$ & $\begin{array}{r}157 \pm 4 \\
(22)\end{array}$ & $\begin{array}{l}71 \pm 16 \\
(23)\end{array}$ & $\begin{array}{l}\mathrm{S} / \mathrm{I} P<0.001 \\
\mathrm{C} / \mathrm{I} P<0.001\end{array}$ \\
\hline Insulin $(\mu U / m l)$ & $\begin{array}{l}54.1 \pm 7.6 \\
(19)\end{array}$ & $\begin{array}{r}62.4 \pm 9.9 \\
(22)\end{array}$ & $\begin{array}{l}588.8 \pm 89.7 \\
(23)\end{array}$ & $\begin{array}{l}\mathrm{S} / \mathrm{I} P<0.001 \\
\mathrm{C} / \mathrm{I} P<0.001\end{array}$ \\
\hline FFA ( $\mu \mathrm{mol} /$ liter $)$ & $\begin{array}{c}434 \pm 21 \\
(19)\end{array}$ & $\begin{array}{r}451 \pm 24 \\
(22)\end{array}$ & $\begin{array}{c}429 \pm 42 \\
(23)\end{array}$ & \\
\hline Triglyceride $(m g / d l)$ & $\begin{array}{c}152 \pm 18 \\
(19)\end{array}$ & $\begin{array}{r}217 \pm 9 \\
(22)\end{array}$ & $\begin{array}{r}109 \pm 9 \\
(23)\end{array}$ & $\begin{array}{l}\mathrm{C} / \mathrm{S} P<0.005 \\
\mathrm{~S} / \mathrm{I} P<0.001 \\
\mathrm{C} / \mathrm{I} P<0.05\end{array}$ \\
\hline \multicolumn{5}{|c|}{ Liver and muscle triglyceride glycogen concentrations } \\
\hline Liver triglyceride $(\mu \mathrm{mol} / \mathrm{g})$ & $\begin{array}{c}15.1 \pm 0.6 \\
(6)\end{array}$ & $\begin{array}{r}18.0 \pm 0.3 \\
(6)\end{array}$ & $\begin{array}{c}17.9 \pm 2.1 \\
(6)\end{array}$ & $\mathrm{C} / \mathrm{S} P<0.05$ \\
\hline $\begin{array}{l}\text { Gastrocnemius triglyceride } \\
\quad(\mu \mathrm{mol} / \mathrm{g})\end{array}$ & $\begin{array}{c}7.7 \pm 1.1 \\
(6)\end{array}$ & $\begin{array}{r}11.8 \pm 2.4 \\
(6)\end{array}$ & $\begin{array}{c}7.2 \pm 0.9 \\
(6)\end{array}$ & \\
\hline Liver glycogen $(\mu g / m g)$ & $\begin{array}{c}82.4 \pm 4.3 \\
(8)\end{array}$ & $\begin{array}{r}110.1 \pm 5.6 \\
(8)\end{array}$ & $\begin{array}{c}77.2 \pm 9.7 \\
(11)\end{array}$ & $\begin{array}{l}\mathrm{C} / \mathrm{S} P<0.05 \\
\mathrm{~S} / \mathrm{I} P<0.01\end{array}$ \\
\hline Soleus glycogen $(\mu g / m g)$ & $\begin{array}{c}5.9 \pm 0.5 \\
(7)\end{array}$ & $\begin{array}{r}5.7 \pm 0.6 \\
(8)\end{array}$ & $\begin{array}{c}5.0 \pm 0.4 \\
(11)\end{array}$ & \\
\hline
\end{tabular}

Results are mean \pm SEM. C, Chow-fed controls; S, sugar-supplemented controls; I, insulin-treated animals. Number of determinations shown in parentheses.

After 2 wk of treatment there were no differences in body weight, epididymal fat pad weight, or adipose cell size among the three experimental groups. In insulin-treated animals, mean plasma glucose concentration, measured in the morning without food restriction, was $\sim 50 \%$ that of control animals, and mean plasma insulin concentration was tenfold greater, confirming a significant degree of hyperinsulinemia. There were no differences in plasma free fatty acid concentration, but triglyceride concentration was significantly increased in sugar-supplemented controls and was lowest in the insulintreated animals. Liver weight and glycogen content were highest in the sugar-supplemented control groups and no differences were observed in muscle triglyceride or glycogen content among the three experimental groups.

After 2 wk of insulin treatment, chow consumptions for the insulin-treated animals and sugar-supplemented controls were equal $(15.5 \pm 0.6$ and $15.5 \pm 0.5 \mathrm{~g} / \mathrm{d}$ per rat, respectively), but lower than that of chow-fed controls $(20.6 \pm 0.7 \mathrm{~g} / \mathrm{d}$ per rat). However, the lower chow intakes were compensated by equivalent increases in sucrose consumption in these two groups $(6.0 \pm 1.0$ and $5.1 \pm 0.7 \mathrm{~g} / \mathrm{d}$ per rat, respectively). Total caloric intake for all groups was, therefore, approximately the same.

After $6 \mathrm{wk}$ of treatment, the mean daily consumption of chow and sucrose was the same in insulin-treated animals and the sugar-supplemented controls (chow: $15.5 \pm 0.7$ vs. $15.5 \pm 0.6$; sucrose: $6.8 \pm 0.7$ vs. $5.8 \pm 0.5 \mathrm{~g} /$ rat per $\mathrm{d}$, respectively). Chow fed controls weighed slightly more than insulin-treated animals, but there was no significant difference in body weight between insulin-treated animals and sugar-supplemented controls. Epididymal fat pad weight and adipose cell size were greatest in insulin-treated animals, but not significantly so. Mean plasma glucose concentration in insulin-treated animals continued to be slightly $<50 \%$ that of controls. However, plasma insulin 


\begin{tabular}{|c|c|c|c|c|}
\hline & $\begin{array}{l}\text { Chow-fed } \\
\text { controls }\end{array}$ & $\begin{array}{l}\text { Sugar-supplemented } \\
\text { controls }\end{array}$ & $\begin{array}{l}\text { Insulin-treated } \\
\text { animals }\end{array}$ & $\begin{array}{l}\text { Group } \\
\text { comparisons }\end{array}$ \\
\hline \multicolumn{5}{|l|}{ Body and organ weights } \\
\hline Body weight $(g)$ & $\begin{array}{r}425 \pm 7 \\
(5)\end{array}$ & $\begin{array}{r}407 \pm 11 \\
(20)\end{array}$ & $\begin{array}{c}399 \pm 10 \\
(14)\end{array}$ & $\mathrm{C} / \mathrm{I} P<0.05$ \\
\hline Liver weight $(g)$ & $\begin{array}{c}15.90 \pm 0.46 \\
(5)\end{array}$ & $\begin{array}{c}18.60 \pm 0.80 \\
(10)\end{array}$ & $\begin{array}{c}16.31 \pm 1.00 \\
(5)\end{array}$ & $\mathrm{C} / \mathrm{S} P<0.02$ \\
\hline Fat pad weight $(g)$ & $\begin{array}{c}4.08 \pm 0.35 \\
(5)\end{array}$ & $\begin{array}{c}4.90 \pm 0.31 \\
(13)\end{array}$ & $\begin{array}{c}4.97 \pm 0.32 \\
(8)\end{array}$ & \\
\hline Adipose cell size ( $\mu$ g lipid/cell) & $\begin{array}{c}0.268 \pm 0.014 \\
\text { (2) }\end{array}$ & $\begin{array}{c}0.308 \pm 0.025 \\
(5)\end{array}$ & $\begin{array}{c}0.359 \pm 0.039 \\
\text { (3) }\end{array}$ & \\
\hline \multicolumn{5}{|l|}{ Plasma concentrations } \\
\hline Glucose $(m g / d l)$ & $\begin{array}{c}142 \pm 5 \\
(5)\end{array}$ & $\begin{array}{r}134 \pm 3 \\
(20)\end{array}$ & $\begin{array}{c}63 \pm 10 \\
(14)\end{array}$ & $\begin{array}{l}\mathrm{S} / \mathrm{I} P<0.001 \\
\mathrm{C} / \mathrm{I} P<0.001\end{array}$ \\
\hline Insulin $(\mu U / m l)$ & $\begin{array}{c}55.0 \pm 3.1 \\
(5)\end{array}$ & $\begin{array}{r}51.5 \pm 4.9 \\
(20)\end{array}$ & - & \\
\hline FFA $(\mu \mathrm{mol} /$ liter $)$ & $\begin{array}{c}840 \pm 75 \\
(5)\end{array}$ & $\begin{array}{c}1,027 \pm 113 \\
(20)\end{array}$ & $\begin{array}{c}701 \pm 73 \\
(14)\end{array}$ & $\mathrm{S} / \mathrm{I} P<0.02$ \\
\hline Triglyceride $(m g / d l)$ & $\begin{array}{c}142 \pm 4 \\
(5)\end{array}$ & $\begin{array}{r}207 \pm 17 \\
(20)\end{array}$ & $\begin{array}{c}140 \pm 16 \\
(14)\end{array}$ & $\begin{array}{l}\mathrm{C} / \mathrm{S} P<0.005 \\
\mathrm{~S} / \mathrm{I} P<0.001\end{array}$ \\
\hline \multicolumn{5}{|c|}{ iver and muscle triglyceride and glycogen concentrations } \\
\hline Liver triglyceride $(\mu \mathrm{mol} / \mathrm{g})$ & $\begin{array}{c}20.1 \pm 2.4 \\
(5)\end{array}$ & $\begin{array}{r}15.8 \pm 0.4 \\
(10)\end{array}$ & $\begin{array}{c}14.2 \pm 1.0 \\
(5)\end{array}$ & \\
\hline Gastrocnemius triglyceride $(\mu \mathrm{mol} / \mathrm{g})$ & $\begin{array}{c}13.0 \pm 1.7 \\
(5)\end{array}$ & $\begin{array}{r}12.6 \pm 1.3 \\
(10)\end{array}$ & $\begin{array}{c}13.8 \pm 0.8 \\
(5)\end{array}$ & \\
\hline Liver glycogen $(\mu g / m g)$ & $\begin{array}{c}64.9 \pm 3.9 \\
(5)\end{array}$ & $\begin{array}{r}94.0 \pm 5.2 \\
(16)\end{array}$ & $\begin{array}{c}80.9 \pm 8.1 \\
(11)\end{array}$ & $\mathrm{C} / \mathrm{S} P<0.001$ \\
\hline Soleus glycogen $(\mu g / m g)$ & $\begin{array}{c}6.0 \pm 0.4 \\
(5)\end{array}$ & $\begin{array}{r}6.8 \pm 0.3 \\
(16)\end{array}$ & $\begin{array}{c}6.9 \pm 0.4 \\
(11)\end{array}$ & \\
\hline Gastrocnemius glycogen $(\mu g / m g)$ & - & $\begin{array}{r}6.7 \pm 0.5 \\
(6)\end{array}$ & $\begin{array}{c}6.5 \pm 0.7 \\
(6)\end{array}$ & \\
\hline
\end{tabular}

Reports are mean \pm SEM. C, Chow-fed controls; S, sugar-supplemented controls; I, insulin-treated animals. Number of determinations shown in parentheses.

concentrations could not be measured accurately in these animals because of the presence of nonspecific binding of ${ }^{125} \mathrm{I}$ insulin tracer, presumably due to the development of circulating anti-insulin antibodies.

Mean plasma free fatty acids and triglycerides were highest in sugar-supplemented controls, as were liver weight and glycogen content. There were no significant differences in muscle glycogen or triglyceride content among the groups.

The compositional analyses of carcasses from sugar-supplemented controls and animals treated with insulin for 6 wk are shown in Table III. Total carcass weight was the same in both groups. Although fat content was greater and fat-free mass lower in insulin-treated animals, these differences were not statistically significant. There were no differences in protein or ash content.
Adipose cell size of chow-fed control, sucrose-supplemented control, and insulin-treated animals. 2 wk of insulin treatment did not alter the size of the cells as compared with either control group (Table I). After 6 wk of treatment, cell size was increased in all groups and, although the insulin treated animals had the largest cell size, the differences were not statistically significant.

Total glucose, utilization in adipose cells. The effect of insulin $(0-1,000 \mu \mathrm{U} / \mathrm{ml})$ on total glucose utilization, defined as the sum of the 1-carbon atom of glucose incorporated into ${ }^{14} \mathrm{CO}_{2}$ and $\left[{ }^{14} \mathrm{C}\right]$ triglyceride glycerol and fatty acids, was compared in adipose cells isolated from chow-fed controls, sugarsupplemented controls, and insulin-infused animals after 2 and $6 \mathrm{wk}$ of treatment. Total glucose utilization was not significantly different in cells from the three experimental 
Table III. Carcass Composition of Control and Insulin-treated Rats at End of 6-wk Study

\begin{tabular}{lcc}
\hline & Sugar supplemented & Insulin treated \\
\hline Total carcass weight $(g)$ & $352.5 \pm 9.1$ & $358.7 \pm 12.4$ \\
Dried weight $(g)$ & $117.1 \pm 9.0$ & $129.6 \pm 8.1$ \\
$\%$ Total weight & 33.2 & 36.1 \\
Water $(g)$ & $235.4 \pm 12.8$ & $229.1 \pm 7.3$ \\
\% Total weight & 67.8 & 63.9 \\
Protein $(g)$ & $62.9 \pm 3.1$ & $62.2 \pm 6.0$ \\
$\%$ Total weight & 17.8 & 17.6 \\
Ash $(g)$ & $10.9 \pm 0.7$ & $10.5 \pm 1.1$ \\
$\%$ Total weight & 3.1 & 2.9 \\
Fat $(g)$ & $37.4 \pm 5.8$ & $52.8 \pm 4.2$ \\
$\%$ Total weight & 10.6 & 14.7 \\
Fat-free mass $(g)$ & $315.2 \pm 10.0$ & $306.0 \pm 12.3$ \\
$\%$ Total weight & 89.4 & 85.3 \\
\hline
\end{tabular}

Results are mean \pm SEM. There were no statistically significant differences between the groups. Six animals were included in each group.

groups at low insulin concentrations $(0-10 \mu \mathrm{U} / \mathrm{ml})$ after $2 \mathrm{wk}$, nor in the absence of insulin after $6 \mathrm{wk}$ of treatment. Increasing insulin concentrations, in the presence of $0.1 \mathrm{mM}$ glucose, enhanced total glucose utilization in adipose cells from all groups in a dose-dependent manner (Figs. 1 and 2). Adipose cells from rats treated with insulin for 2 and 6 wk utilized approximately two times more glucose than cells from either control group over most of the insulin dose-response curve, but the concentrations of insulin needed to reach half-maximal stimulation $(\sim 15 \mu \mathrm{U} / \mathrm{ml})$ did not change.

Maximal rates of total glucose utilization were assessed in adipose cells from control and insulin-treated rats by measuring glucose utilization in the presence of $10 \mathrm{mM}$ glucose and $1,000 \mu \mathrm{U} / \mathrm{ml}$ insulin. Compared with both control groups, insulin treatment increased the maximal capacity for glucose

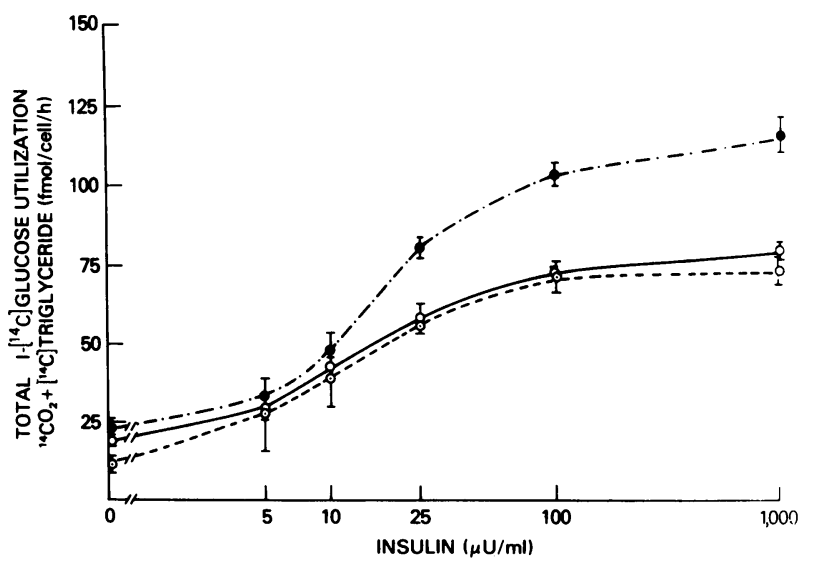

Figure 1. Effect of 2-wk insulin treatment on insulin-dependent stimulation of total $\left[1-{ }^{14} \mathrm{C}\right]$ glucose utilization in rat adipose cells. "Total" glucose utilization: sum of glucose carbon incorporation into labeled $\mathrm{CO}_{2}$ plus labeled triglyceride. Incubation time, $60 \mathrm{~min}$. Data are mean \pm SE of 4-6 experiments. $\bigcirc$, Chow-fed controls; $\odot$, sugarsupplemented controls; $\bullet$, insulin treated.

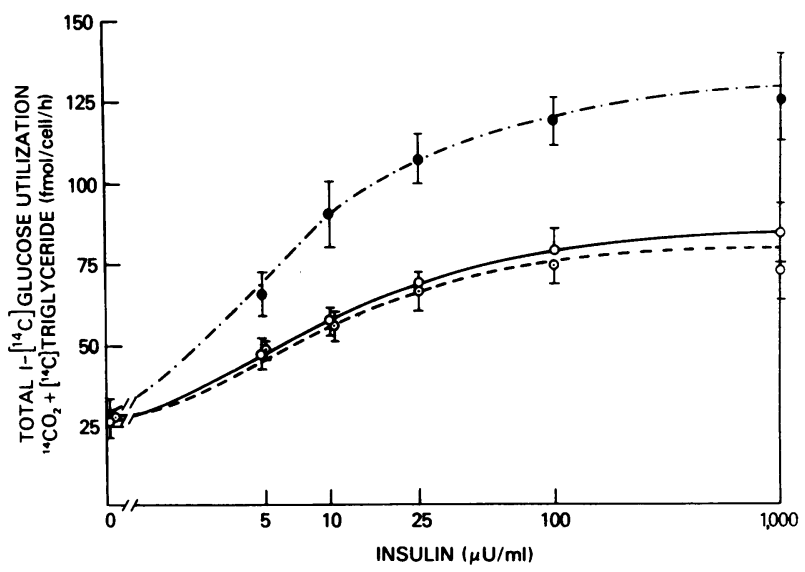

Figure 2. Effect of 6-wk insulin treatment on insulin-dependent stimulation of total $\left[1-{ }^{14} \mathrm{C}\right]$ glucose utilization in rat adipose cells. "Total" glucose utilization: sum of glucose carbon incorporation into labeled $\mathrm{CO}_{2}$ plus labeled triglyceride. Incubation time, $60 \mathrm{~min}$. Data are mean $\pm S E$ of 4-6 experiments.

utilization two- to threefold. After 2 wk of insulin treatment, the maximal capacity for glucose utilization was $2,154 \pm 139$ $\mathrm{fmol} / \mathrm{cell}$ per $\mathrm{h}$ in cells from insulin-treated rats, compared with $679 \pm 56$ and $802 \pm 92$ in cells from chow fed and sugarsupplemented controls, respectively. After 6 wk of treatment, the corresponding maximal rates of glucose utilization were $1,058 \pm 249,480 \pm 32$, and $457 \pm 27 \mathrm{fmol} /$ cell per $\mathrm{h}$, respectively.

When incorporation of $\left[1-{ }^{14} \mathrm{C}\right]$ glucose into $\mathrm{CO}_{2}$, triglycerideglycerol, and triglyceride fatty acids was examined, insulin treatment resulted in increases in the incorporation of glucose into $\mathrm{CO}_{2}$ and triglyceride fatty acids without significant changes in the incorporation into triglyceride glycerol in both 2- (Fig. 3) and 6-wk (Fig. 4) treated rats.

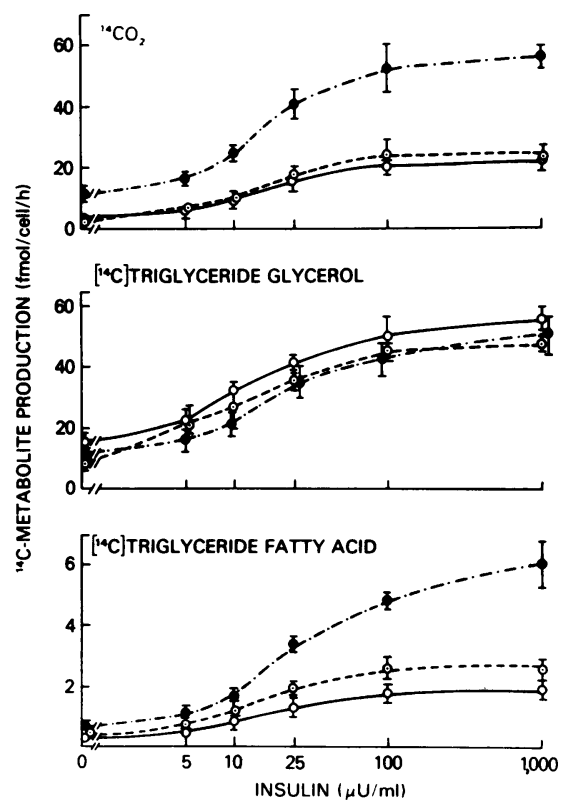

Figure 3. Effect of 2-wk insulin treatment on insulin-dependent stimulation of $\left[1-{ }^{14} \mathrm{C}\right]$ glucose metabolism in rat adipose cells. Labeled carbon incorporation into respective parameters is indicated. Incubation time, $60 \mathrm{~min}$. Data are mean $\pm \mathrm{SE}$ of 4-6 experiments. $O$, Chowfed controls; $\odot$, sugar-supplemented controls, $\bullet$, insulin treated. 


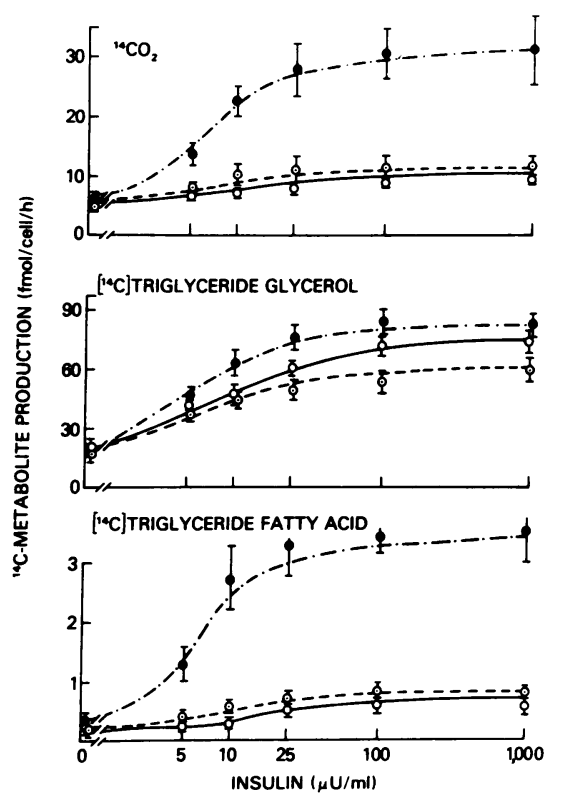

Figure 4. Effect of 6-wk insulin treatment on insulin-dependent stimulation of $\left[1-{ }^{14} \mathrm{C}\right]$ glucose metabolism in rat adipose cells. Labeled carbon incorporation into respective parameters is indicated. Incubation time, $60 \mathrm{~min}$. Data are mean $\pm \mathrm{SE}$ of 4-6 experiments. $O$, Chowfed controls; $\odot$, sugar-supplemented controls; $\bullet$, insulin treated.

Steady state ${ }^{125}$ I-insulin binding to adipose cells. Examination of steady state ${ }^{125}$ I-insulin binding to adipose cells isolated from the three groups revealed that 2 and $6 \mathrm{wk}$ of insulin treatment increased insulin binding by $\sim 30$ and $50 \%$, respectively, when compared with either the chow fed or the sugar-supplemented controls (Fig. 5).

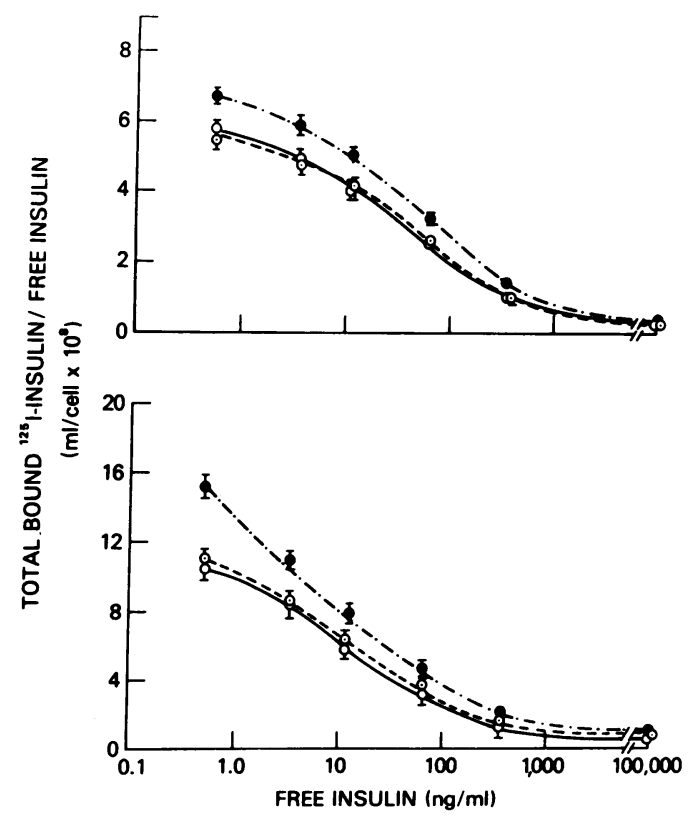

Figure 5. Effect of 2-wk (top) and 6-wk (bottom) insulin treatment on insulin binding to rat adipose cells. Insulin binding measured with ${ }^{125} \mathrm{I}$-insulin at $24^{\circ} \mathrm{C}$ for $60 \mathrm{~min}$. Data are mean $\pm \mathrm{SE}$ of three experiments. $০$, Chow-fed controls; $\odot$, sugar-supplemented controls; $\bullet$, insulin treated.
Glucose transport in adipose cells. Glucose transport was assessed in adipose cells from control and insulin-treated rats by examining the initial rate of 3-O-methylglucose uptake by these cells. As illustrated in Figs. 6 and 7, there were no differences in the basal rates of 3-O-methylglucose transport among the three experimental groups after 2 or $6 \mathrm{wk}$ of treatment. After $2 \mathrm{wk}$, insulin stimulated 3-O-methylglucose transport was increased approximately twofold over the entire insulin dose-response curve in cells from insulin-treated rats compared with the control groups. However, the concentrations of insulin needed to reach half-maximal stimulation $(\sim 15$ $\mu \mathrm{U} / \mathrm{ml}$ ) did not change (Fig. 6). This effect of insulin treatment on insulin-stimulated transport was not observed in rats treated for 6 wk (Fig. 7).

Epinephrine-stimulated lipolysis in adipose cells. Lipolysis was determined by measuring the amounts of glycerol and free fatty acids released into the incubation medium as a function of increasing concentrations of epinephrine. Epinephrine stimulated lipolytic activity by severalfold in cells from both controls and insulin-treated rats. In addition, insulin inhibited epinephrine-stimulated lipolytic activity in a dosedependent manner $(0-100 \mu \mathrm{U} / \mathrm{ml})$ in cells from controls and insulin-treated rats (data not shown). However, there were no significant differences between any of the groups after either 2 or 6 wk of treatment.

Soleus muscle metabolism. The data on basal and insulinstimulated glucose metabolism by incubated strips of soleus muscle from chow fed, sugar supplemented, and insulintreated rats after 2 wk treatment are shown in Fig. 8. After 2 wk of treatment, there were no significant differences between the chow fed and sugar-supplemented controls in either basal or insulin-stimulated rates of glycolysis, glycogen synthesis, or total glucose metabolism. In insulin-treated rats, glycogen synthesis and total glucose metabolism were significantly increased in response to insulin stimulation, compared with either control group. Maximal rates of insulin stimulated glycogen synthesis were $5.05 \pm 0.36 \mathrm{nmol} / \mathrm{mg}$ per $\mathrm{h}$ in insulintreated rats, compared with $3.76 \pm 0.31(P<0.05)$ and $3.61 \pm 0.19$

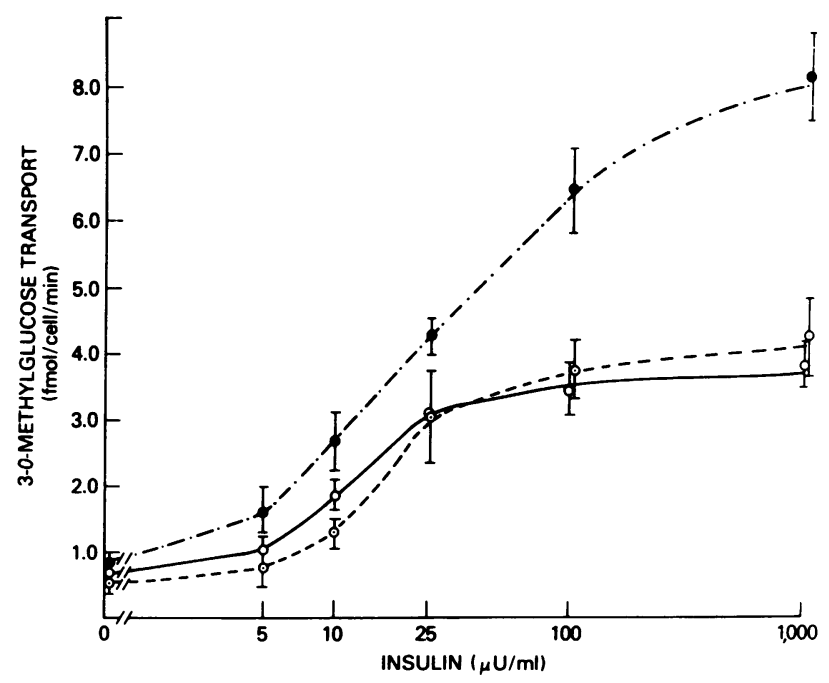

Figure 6. Effect of 2-wk insulin treatment on 3-O-methylglucose transport in rat adipose cells. Data are mean \pm SE of 4-5 experiments. $\circ$, Chow-fed controls; $\odot$, sugar-supplemented controls; $\bullet$, insulin treated. 


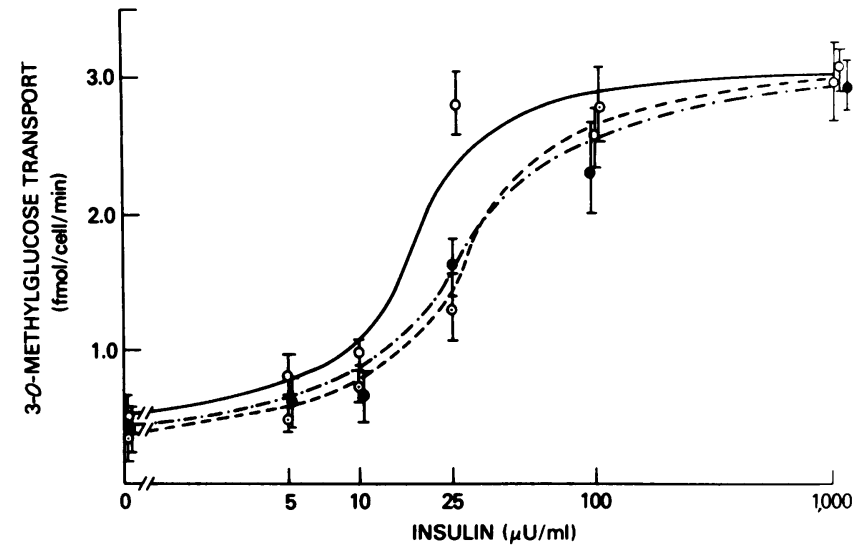

Figure 7. Effect of 6-wk insulin treatment on 3-O-methylglucose transport in rat adipose cells. Data are mean \pm SE of 4-5 experiments. $\circ$, Chow-fed controls; $\odot$, sugar-supplemented controls; $\bullet$, insulin treated.

$(P<0.01)$ in chow fed and sugar-supplemented controls, respectively. Corresponding rates of total glucose metabolism were $11.49 \pm 0.54 \mathrm{nmol} / \mathrm{mg}$ per $\mathrm{h}$ in muscles from insulintreated rats, compared with $9.85 \pm 0.42(P<0.05)$ and $9.99 \pm 0.42$ $(P<0.05)$ in the controls. However, insulin sensitivity, defined as the concentration of insulin required to achieve halfmaximal stimulation of glucose metabolism, did not change. In addition, insulin treatment had no significant effect on either basal rates of glucose metabolism or on insulin-stimulated glycolysis.

In contrast to the observed changes in adipose cell metabolism, 6 wk of insulin treatment did not alter glycolysis, glycogenesis, or total glucose utilization in soleus muscle when compared with sugar-supplemented controls.

\section{Discussion}

Previous studies have examined the effects of experimental chronic hyperinsulinemia on glucose transport and metabolism

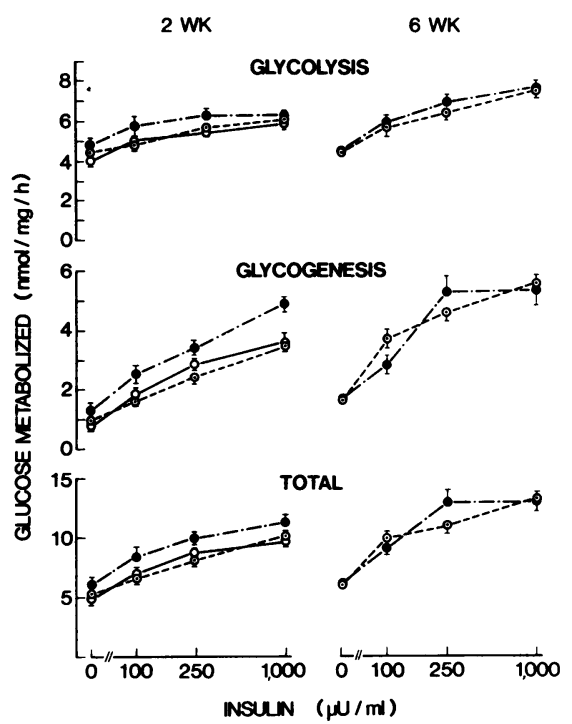

Figure 8. Effect of 2- and 6-wk insulin treatment on glucose metabolism by strips of rat soleus muscle. Data are mean $\pm \operatorname{SE}(n=5-9)$. $\circ$, Chow-fed controls; $\odot$, sugar-supplemented controls; $\bullet$, insulin treated. and insulin binding in adipose cells (14-17). In these studies, the hyperinsulinemia was induced by injection of NPH or Ultratard insulin over a period of $\sim 2$ wk. These studies demonstrated that insulin binding to adipose cells was reduced by $50-60 \%$, and there was a marked rightward shift in the insulin-dose response for glucose transport. In contrast to this evidence for down-regulation of the insulin-stimulated glucose transport system, a marked increase in total glucose metabolism was observed in response to hyperinsulinemia.

The present study was undertaken to examine and clarify the effects of experimental hyperinsulinemia on glucose transport and metabolism and insulin binding in adipose cells and to determine whether similar effects occur in skeletal muscle. In contrast to previous studies, continuous hyperinsulinemia was produced using Alzet osmotic minipumps containing regular purified pork insulin, and measurements were made after both 2 and $6 \mathrm{wk}$ of treatment. We found that continuous hyperinsulinemia for either 2 or 6 wk did not result in the development of insulin resistance in either adipose cells or skeletal muscle. On the contrary, after 2 wk of insulin administration, insulin binding to adipose cells was increased rather than decreased, as has been reported previously by Kobayashi and Olefsky (14) and Whittaker et al. (15), and nearly twofold increases in total insulin-stimulated glucose metabolism by adipose cells were observed at insulin concentrations $>10$ $\mu \mathrm{U} / \mathrm{ml}$. In addition, we have extended the period of hyperinsulinemia to $6 \mathrm{wk}$, following which insulin binding to adipose cells and insulin-stimulated glucose metabolism remained increased. Despite these increases in insulin binding and glucose metabolism, the concentration of insulin required to attain half-maximal stimulation did not change, indicating no change in insulin sensitivity. Thus, our results are inconsistent with the hypothesis that high circulating insulin concentrations for 2 to $6 \mathrm{wk}$ result in down-regulation of the insulin receptor.

The explanation for the differences in insulin binding observed in the present study and those previously reported after 2 wk of insulin treatment is not clear, but may be due to the difference in experimental methods. The studies by Kobayaski and Olefsky (14) and Whittaker et al. (15) employed once or twice daily injections of intermediate or long-acting insulin preparations, whereas we used a continuous insulin infusion technique. It is possible that continuous hyperinsulinemia produced with osmotic minipumps, compared with intermittent insulin administration, may have two opposing effects on insulin receptors, a growth effect and down-regulation. Whereas pulsatile insulin treatment may result in a preferential down-regulation of insulin receptors, it is possible that continuous insulin delivery may cause a greater increase in the number of insulin receptors through increased protein synthesis and a smaller down-regulation of receptor number and/or binding affinity. The net effect would be a moderate increase in insulin binding.

After 2 wk of continuous hyperinsulinemia, there was also an increase in insulin-stimulated glucose transport .without alteration of basal glucose transport activity or insulin sensitivity, consistent with the changes in glucose metabolism. This potentiation of glucose transport activity was no longer observed when insulin was administered for $6 \mathrm{wk}$, possibly due to the decreased insulin responsiveness that normally occurs in the larger adipose cells of older rats where glucose transport may no longer be the rate-limiting step for glucose metabolism. Under these conditions, the increased metabolic activity in 
adipose cells from insulin-treated rats may be due to postreceptor increases in glucose metabolism, without an increase in glucose transport activity. This is supported by the finding that 6 wk of chronic hyperinsulinemia, assessed by measuring glucose metabolism at a high glucose concentration (10 $\mathrm{mM})$ and in the presence of a maximally stimulating concentration of insulin $(1,000 \mu \mathrm{U} / \mathrm{ml})$, increased the total capacity for glucose metabolism beyond glucose transport by approximately threefold after 2 wk of insulin treatment and by twofold after 6 wk of treatment. The present studies also suggest that there is a change in the coupling site between the insulin receptor and activation of glucose transport. Although an increase in insulin binding was observed, there were no increases in insulin sensitivity for glucose transport and metabolism, as would be expected to occur with increased insulin binding. These effects of chronic hyperinsulinemia on glucose transport and metabolism by the adipose cells occurred in the absence of differences in cell size.

The effect of hyperinsulinemia on lipolysis, another important metabolic parameter of the adipose cell, was also studied. Hyperinsulinemia had no effect on the epinephrine dose-response stimulation of glycerol or free fatty acid release from adipose cells. In addition, no changes in the antilipolytic effect of insulin were observed. These findings indicate that chronic hyperinsulinemia has differential effects on glucose metabolism and lipolysis.

The effects of 2 and 6 wk of hyperinsulinemia on muscle metabolism were also studied. After 2 wk of treatment, insulinstimulated glycogen synthesis and total glucose metabolism were significantly increased in soleus muscle strips. This effect was not observed after 6 wk of insulin treatment, although comparisons were only made between insulin-treated animals and sugar-supplemented controls. These studies suggest that similar increases in glucose metabolism can be observed in skeletal muscle as in adipose cells, although the effects are smaller and apparently lost after 6 wk of treatment.

It is clear from our data that the observed increases in glucose metabolism in adipose cells and muscle are due to the chronic hyperinsulinemia (associated with decreased plasma glucose concentrations), and not to effects of hyperphagia or a high carbohydrate diet, since total food consumption was not significantly different among the three experimental groups, and the animals treated with insulin consumed the same quantities of chow and sucrose as the sugar-supplemented controls. Adipose cells from the latter animals metabolized glucose almost identically to those from animals given access to chow alone.

An unanswered question is why the adipose cells from insulin-treated animals did not become larger than those from controls when increased rates of lipogenesis were observed in vitro. A possible explanation is that in vivo, the mean plasma glucose concentration of hyperinsulinemic rats was only $50 \%$ that of the control animals. This lower glucose concentration may have been a limiting factor for lipogenesis in vivo. Other possible contributing factors are that the hyperinsulinemic animals may have had an insulin-induced increase in the metabolic rate or activation of sympathetic nervous systemmediated metabolism secondary to hyperinsulinemia and/or relative hypoglycemia. Although metabolic rates or plasma catecholamines were not measured in this study, catecholamine concentrations have been reported to be increased in chronically insulin infused rats (33).
It is also possible that the lower plasma glucose concentrations in the insulin-treated animals could have affected insulin binding and action in adipose cells and muscle tissue, although the mechanism by which this might occur is unknown. One possible explanation is that increased insulin-stimulated glucose transport and metabolism could be secondary to chronic stimulation of the sympatho-adrenal system by chronic hypoglycemia. It has been shown previously that high concentrations of epinephrine result in an increase in the rate of glucose transport in both frog (34) and mammalian (35) muscle and that chronic administration of epinephrine to rats results in an apparent adaptation so that there is less inhibition of insulin release and increased sensitivity to exogenous insulin in vivo (36). These effects appear to be mediated by beta adrenergic receptors. In recent studies in humans using the euglycemic-hyperinsulinemic clamp technique, chronic administration of the $\beta_{2}$-adrenergic agonist, terbutaline, has been shown to result in significant increases in both total and nonoxidative glucose disposal rates during insulin infusion without any change in basal rates of glucose turnover (37). These studies suggest that chronic stimulation of the sympathoadrenal system may lead to decreased beta receptor sensitivity, and that this may, in turn, lead to increased insulin action in peripheral tissues, particularly muscle. This is clearly only one of many possible mechanisms by which chronic hypoglycemia could contribute indirectly to the increases in insulin-stimulated glucose transport and metabolism observed in the insulintreated animals in our study.

Recently, investigations of the development of insulin resistance in the genetically obese Zucker rat $(\mathrm{fa} / \mathrm{fa})$ have indicated that early in the development of this syndrome there is a marked potentiation of insulin-stimulated glucose transport and metabolism $(2,38)$. These studies were undertaken when the rats were very young but already hyperinsulinemic. The results parallel the present studies with experimentally induced hyperinsulinemia and suggest that hyperinsulinemia has at least two effects. Early in the development of hyperinsulinemia, insulin could have a growth-promoting effect, increasing overall cell protein content. This is reflected by increased insulin binding and glucose transport and metabolism in adipose cells. It is not until later in the syndrome that insulin resistance develops, as reflected by decreased responses to insulin. Based on these data in young obese Zucker rats, it is possible that if insulin had been administered for longer than 6 wk in our studies, insulin resistance may have developed. However, this would be difficult to determine in the present model of hyperinsulinemia because the changes associated with enlarging adipose cells are themselves associated with the development of insulin resistance.

Trimble et al. (33) have also investigated the effect of hyperinsulinemia, produced by constant intravenous insulin infusions for $\mathbf{8 d}$, on in vitro and in vivo insulin responsiveness in the rat. Their studies demonstrated increases in glucose metabolism in vivo, as well as increased glucose transport and lipogenesis in isolated adipose cells. Their data in isolated adipose cells are very similar to those reported here.

Since glucose transport seems to be a primary site altered by hyperinsulinemia of 2 wk duration, a possible mechanism for the potentiation of insulin-stimulated glucose transport in adipose cells from insulin-treated animals is currently being investigated. Recently, it has been demonstrated in several models of insulin resistance that the total number of glucose 
transporters in adipose cells, as shown by Cushman and Wardzala (39) and Suzuki and Kono (40), is markedly altered by increased cell size (41), increased fat content in the diet (42), and the diabetes induced by streptozotocin (43). As previously hypothesized by Kobayashi and Olefsky (16), the present studies suggest that the number of glucose transporters in adipose cells may be increased by chronic hyperinsulinemia. Measurements of the number of glucose transporters in plasma membranes and the low density microsomal pool are presently being undertaken. Recent reports by Kahn et al. (44) and Guerre-Millo et al. (45) indicate that the hyperinsulinemia produced by insulin infusion with osmotic minipumps and the in vivo hyperinsulinemia in young obese Zucker rats (fa/ fa) may result in increases in the number of glucose transporters in the adipose cells from these animals. An increase in the number of transporters may be a reflection of the growth effect of early hyperinsulinemia. The loss of any changes in glucose transport activity after 6 wk of insulin administration may be due to loss in total glucose transporters associated with a greater insulin resistance of the enlarging adipose cell (42).

\section{Acknowledgments}

These studies were supported, in part, by grant R01 AM 26317 (Dr. Horton) from the National Institutes of Health.

\section{References}

1. Crettaz, M., M. Prentki, D. Zaninetti, and B. Jeanrenaud. 1980. Insulin resistance in soleus muscle from obese Zucker rats. Involvement of several defective sites. Biochem. J. 186:525-534.

2. Cushman, S. W., M. J. Zarnowski, A. J. Franzusoff, and L. B. Salans. 1978. Alterations in glucose metabolism and its stimulation by insulin in isolated adipose cells during the development of genetic obesity in the Zucker fatty rat. Metab. Clin. Exp. 27:1930-1940.

3. DiGirolamo, M., and D. Rudman. 1968. Variations in glucose metabolism and sensitivity to insulin of the rat's adipose tissue, in relation to age and body weight. Endocrinology. 82:1133-1141.

4. LeMarchand-Brustel, Y., and B. Jeanrenaud. 1978. Pre- and post-weaning studies on development of obesity in $\mathrm{mdb} / \mathrm{mdb}$ mice. Am. J. Physiol. 234(Endocrinol. Metab. Gastrointest. Physiol. 3):E568E574.

5. LeMarchand-Brustel, Y., B. Jeanrenaud, and P. Freychet. 1978. Insulin binding and effects in isolated soleus muscle of lean and obese mice. Am. J. Physiol. 234(Endocrinol. Metab. Gastrointest. Physiol. 3):E348-E358.

6. Livingston, J. N., P. Cuatrecasas, and D. H. Lockwood. 1972. Insulin insensitivity of large fat cells. Science (Wash. DC). 177:626628.

7. Olefsky, J. M. 1976. The effects of spontaneous obesity on insulin binding, glucose transport, and glucose oxidation of isolated rat adipocytes. J. Clin. Invest. 56:842-851.

8. Olefsky, J. M., P. A. Carpo, H. Ginsberg, and G. M. Reaven. 1975. Metabolic effects of increased caloric intake in man. Metab. Clin. Exp. 24:495-503.

9. Rabinowitz, D., and K. L. Zierler. 1962. Forearm metabolism in obesity and its response to intra-arterial insulin. Characterization of insulin resistance and evidence for adaptive hyperinsulinemia. J. Clin. Invest. 44:2173-2181.

10. Salans, L. B., and J. W. Dougherty. 1971. The effect of insulin upon glucose metabolism by adipose cells of different size. Influence of cell lipid and protein content, age, and nutritional state. J. Clin. Invest. 50:1399-1410.

11. Stern, J. S., P. R. Johnson, M. R. C. Greenwood, L. M. Zucker, and J. Hirsch. 1972. Insulin resistance and pancreatic insulin release in the genetically obese Zucker rat. Proc. Soc. Exp. Biol. Med. 139:66-69.

12. Grey, W., and D. M. Kipnis. 1972. Effect of diet composition on the hyperinsulinemia of obesity. N. Engl. J. Med. 285:827-831.

13. Gavin, J. R., III, J. Roth, P. Jen., and P. Freychet. 1972. Insulin receptors in human circulating cells and fibroblasts. Proc. Natl. Acad. Sci. USA. 69:747-751.

14. Kobayashi, M., and J. M. Olefsky. 1978. Effect of experimental hyperinsulinemia on insulin binding and glucose transport in isolated rat adipocytes. Am. J. Physiol. 235:(Endocrinol. Metab. Gastrointest. Physiol. 4):E53-E62.

15. Whittaker, J., K. G. Alberti, D. A. York, and J. Singh. 1979. The effects of chronic hyperinsulinemia on insulin binding and glucose metabolism in rat adipocytes. Biochem. Soc. Trans. 7:1055-1066.

16. Kobayashi, M., and J. M. Olefsky. 1978. Long-term regulation of adipocyte glucose metabolism transport capacity by circulating insulin by rats. J. Clin. Invest. 62:73-81.

17. Kobayashi, M., and J. M. Olefsky. 1979. Effect of experimental hyperinsulinemia on intracellular glucose metabolism of isolated adipocytes. Diabetologia. 17:111-116.

18. Bringer, J., A. Heldt, and G. M. Grodsky. 1981. Prevention of insulin aggregation by dicarboxylic amino acids during prolonged infusion. Diabetes. 30:83-85.

19. Chan, T. M., and J. H. Exton. 1976. A rapid method for the determination of glycogen content and radioactivity in small quantities of tissue or isolated hepatocytes. Anal. Biochem. 71:96-105.

20. LeMarchand, Y., A. Singh, F. Assimacopoulas-Jeannet, L. Orci, C. Rouiller, and B. Jeanrenaud. 1973. A role for the microtubular system in the release of very low density lipoproteins by perfused mouse livers. J. Biol. Chem. 248:6862-6870.

21. Carew, L. B., and F. W. Hill. 1964. Effects of corn oil on metabolic efficiency of energy utilization by chicks. $J$. Nutr. 83:293299.

22. Rodbell, M. 1964. Metabolism of isolated fat cells. I. Effects of hormones on glucose metabolism and lipolysis. J. Biol. Chem. 239: 375-380.

23. Cushman, S. W. 1970. Structure-function relationship in the adipose cell. I. Ultrastructure of the isolated adipose cell. J. Cell. Biol. 46:326-341.

24. Hirsch, J., and E. Gallian. 1968. Methods for determination of adipose cell size in man and animals. J. Lipid Res. 9:110-119.

25. Cushman, S. W., and L. B. Salans. 1978. Determination of adipose cell size and number in suspensions of isolated rat and human adipose cells. J. Lipid Res. 19:269-273.

26. Foley, J. E., S. W. Cushman, and L. B. Salans. 1978. Glucose transport in isolated rat adipocytes with measurements of L-arabinose uptake. Am. J. Physiol. 234(Endocrinol Metab. Gastrointest. Physiol. 3):E112-E119.

27. Gliemann, J., K. Osterline, J. Vinten, and S. Gammeltoft. 1972. A procedure for measurements of distribution spaces in isolated fat cells. Biochim. Biophys. Acta. 286:1-9.

28. Wieland, O. 1974. Glycerin. In Methods of Enzymatic Analysis, Vol. 2. H. U. Bergmeger, editor. Academic Press, Inc., New York. $1448-1453$.

29. Dole, V. P. 1956. A relation between nonesterified fatty acids in plasma and the metabolism of glucose. J. Clin. Invest. 35:150-154.

30. Ho, R. J., and H. C. Meng. 1969. A simple and ultrasensitive method for determination of free fatty acid by radiochemical assay. Anal. Biochem. 31:426-436.

31. Cushman, S. W., J. J. Heindel, and B. Jeanrenaud. 1973. Cellassociated nonesterified fatty acid levels and their alteration during lipolysis in the isolated mouse adipose cell. J. Lipid Res. 14:632-642.

32. Karakash, C., B. E. Hustvedt, A. Lovo, Y. LeMarchand, and B. Jeanrenaud. 1977. Consequences of ventromedial hypothalamus lesions on metabolism of perfused rat liver. Am. J. Physiol. 232(Endocrinol. Metab. Gastrointest. Physiol. 1):E286-E293.

33. Trimble, E. R., G. C. Weir, A. Gjinovci, F. AssimacopoulosJeannet, R. Benzi, and A. E. Renold. 1984. Increased insulin respon- 
siveness in vivo and in vitro consequent to induced hyperinsulinemia in the rat. Diabetes. 33:444-449.

34. Saha, J., R. Lopez-Mondragon, and H. T. Narahara. 1968. Effect of epinephrine on permeability to sugar and on the production of free glucose in skeletal muscle. J. Biol. Chem. 243:521-527.

35. Bihler, L., P. C. Sawh, and I. G. Sloan. 1978. Dual effect of adrenalin on sugar transport in rat diaphagm muscle. Biochim. Biophys. Acta. 510:349-360.

36. Rousseau-Migneron, S., A. Nadeau, and J. LeBlanc. 1976. Effect of adrenaline on insulin secretion in rats treated chronically with adrenaline. Can. J. Physiol. Pharmacol. 54:870-875.

37. Scheidegger, K., D. C. Robbins, and E. Danforth Jr. 1984. Effects of chronic beta receptor stimulation on glucose metabolism. Diabetes. 33:1144-1149.

38. Lavau, M., M. Guerre-Millo, and C. Guichard. 1983. Hyperresponsiveness of glucose metabolism to insulin in the adipocytes of young hyperinsulinemic obese Zucker rats. Diabetologia. 25:175. (Abstr.)

39. Cushman, S. W., and L. J. Wardzala. 1980. Potential mechanism of insulin action on glucose transport in the isolated rat adipose cell. Apparent translocation of intracellular transport systems to the plasma membrane. J. Biol. Chem. 255:4758-4762.

40. Suzuki, K., and T. Kono. 1980. Evidence that insulin causes translocation of glucose transport activity to the plasma membrane from an intracellular storage site. Proc. Natl. Acad. Sci. USA. 77:25422545.

41. Hissin, P. J., J. E. Foley, L. J. Wardzala, E. Karnieli, I. A. Simpson, L. B. Salans, and S. W. Cushman. 1982. Mechanism of insulin-resistant glucose transport in the enlarged adipose cell of the aged, obese rat. Relative depletion of intracellular glucose transport systems. J. Clin. Invest. 70:780-790.

42. Hissin, P. J., E. Karnieli, I. A. Simpson, L. B. Salans, and S. W. Cushman. 1982. A possible mechanism of insulin resistance in the rat adipose cell with high fat/low-carbohydrate feeding. Depletion of intracellular glucose transport systems. Diabetes. 31:589-592.

43. Karnieli, E., P. J. Hissin, I. A. Simpson, L. B. Salans, and S. W. Cushman. 1981. A possible mechanism of insulin resistance in the rat adipose cell in streptozotocin-induced diabetes mellitus. Depletion of intracellular glucose transport systems. J. Clin. Invest. 68:811-814.

44. Kahn, B. B., E. S. Horton, and S. W. Cushman. 1984. Mechanism by which chronic hyperinsulinemia increases insulinstimulated glucose transport in adipocytes: enlarged intracellular pool of glucose transporters. Clin. Res. 32:399A. (Abstr.)

45. Guerre-Millo, M., L. Wardzala, and M. Lavau. 1985. Increased number of glucose transport systems in adipocytes from young, hyperinsulinemic obese Zucker rats. J. Biol. Chem. 260:2197-2201. 